\title{
Stytt sjúkrahúslega við valkeisaraskurði eftir upptöku flýtibatameðferðar og heimapjónustu
}

\author{
Jóhanna Gunnarsdóttir ${ }^{1}$ læknir, Porbjörg Edda Björnsdóttir¹ hjúkrunarfræðingur, Pórhallur Ingi Halldórsson ${ }^{2,3}$ faraldsfræðingur og tölfræðingur, \\ Guðrún Halldórsdóttir¹ ljósmóðir og hjúkrunarfræðingur, Reynir Tómas Geirsson¹,3 læknir
}

\section{ÁGRIP}

Tilgangur: Kanna hvort sjúkrahúslega við valkeisaraskurði styttist án fjölgunar endurinnlagna með innleiðslu flýtibatameðferðar, og skoða hvaða pættir hefðu áhrif á lengd legu.

Efniviður: Flýtibatameðferð með útskriftarskilyrðum hófst í nóvember 2008 ásamt gæðaeftirliti og ánægjukönnun. Heimapjónusta ljósmæðra var í boði við útskrift innan 48 klst. Legutími allra kvenna sem fæddu einbura með valkeisaraskurði frá 1.11. 2008-31.10. 2009 ( $n=213 ; 182$ i flýtibatameðferð) var borinn saman við legutíma árin 2003 ( $n=199)$ og 2007 ( $n=183)$ og tekið tillit til fyrri fæðinga. Endurinnlagnir og endurkomur 2007 og 2008-9 voru skoðaðar. Ástæður lengri legu, líkamspyngdarstuðull og fleira voru skráð i flýtibatameðferðinni.

Niðurstöður: Miðgildi legutíma styttist marktækt úr 81 i 52 klst milli 2007 og 2008-9. Endurinnlagnir voru fjórar á báðum tímabilum og tíðni endurkoma sambærileg. Árið 2008-9 gátu 66\% heildarhóps útskrifast á innan við 48 klukkustundum. Konur í flýtibatameðferð voru ánægðar með snemmútskrift. Sjúkrahúslega fjölbyrja var styttri 2007 en 2003, en óbreytt hjá frumbyrjum. Fyrri fæðingar höfðu hverfandi áhrif á legutíma 2008-9, pó frumbyrjur yngri en 25 ára í flýtibatameðferð væru líklegri til að liggja inni lengur en í 48 klukkustundir. Engin fylgni var milli líkamspyngdarstuðuls og legutíma. Verkir hömluðu sjaldan útskrift við flýtibatameðferð og 90\% töldu verkjameðhöndlun fullnægjandi eftir heimkomu.

Ályktun: Legutími eftir valkeisaraskurði hefur styst eftir tilkomu flýtibatameðferðar og heimapjónustu. Flestar hraustar konur með eitt barn geta útskrifast snemma eftir valkeisaraskurð, án pess að endurinnlögnum fjölgi.

\section{${ }^{1}$ Kvenna- og barnasviði, 2næringarstofu Landspítala,} 3læknadeild, Hí

Fyrirspurnir: Jóhanna Gunnarsdóttir Akademiska sjukhuset Uppsölum Svípjód

johagun@bjarni.muna.is

Barst: 3. júní 2010, sampykkt til birtingar: 27. maí 2011.

Höfundar tiltaka hvorki styrki né hagsmunatengsl.

\section{Inngangur}

Árlega eru gerðir um 200 valkeisaraskurðir á Landspítala. Flestir fyrirfram ákveðnir keisaraskurðir (valkeisaraskurðir) eru hjá hraustum konum vegna fyrri keisaraskurða eða sitjandastöðu barns. Legutími á sjúkrahúsi eftir keisaraskurð er breytilegur eftir löndum og sjúkrahúsum, en hefur almennt styst undanfarna áratugi. ${ }^{1-5}$ Meðalsjúkrahúslega í Bandaríkjunum styst á 20 ára bili úr sex dögum í prjá árið 2001. ${ }^{1,6}$ Upplýsingar um snemmútskriftir eftir keisaraskurði eru takmarkaðar, en útskrift tveimur dögum eftir aðgerð virðist að jafnaði möguleg fyrir hraustar konur eftir eðlilega meðgöngu og fylgikvillalausa aðgerð. ${ }^{7-10}$ Alvarlegir fylgikvillar við valkeisaraskurði eru fátíðir. ${ }^{10-11}$ Flestir minniháttar fylgikvillar greinast pegar meira en fjórir dagar eru frá aðgerð og endurinnlagnir eru sjaldgæfar.-8

Ekki hefur verið gerð rannsókn á forspárpáttum legutíma eftir keisaraskurð, en eftir legnám hafa verið sýnd tengsl milli legutíma og ógleði sem krefjast meðferðar. ${ }^{12}$ Slembirannsóknir um öryggi og ávinning pess að borða skömmu eftir keisaraskurð, miðað við föstu fyrsta sólarhringinn, hafa bent til óbreyttrar tíðni garnalömunar og sýnt hefur verið fram á stytta sjúkrahúslegu hjá peim sem borða snemma. ${ }^{13}$ Flýtibatameðferð (multimodal enhanced recovery program/fast-track surgery) byggist á peirri tilgátu að preyta eftir aðgerð skýrist af bólguviðbragði vegna aðgerðarinnar, og vöðvaniðurbroti sökum orkuskorts og hreyfingarleysis. Með forvarnarpáttum megi ná skjótari bata og fækka fylgikvillum. Verkjameðferð, stutt fasta, hreyfing og föst fæða skömmu eftir aðgerð eru pví lykilatriði. ${ }^{14}$ 15 Áhersla er lögð á teymisvinnu fagfólks, par með talið svæfingalæknis. ${ }^{14,16}$ Slembirannsókn um ávinning flýtibatameðferðar við valkeisaraskurð er ekki til. Flýtibatameðferð við valkeisaraskurði hófst árið 2002 í Kaupmannahöfn. Um $60 \%$ kvenna sem fengu slíka meðferð árið 2004 gátu útskrifast á öðrum degi og meðallegutími var 2,9 dagar., 10,16

Heimabjónusta ljósmóður er í boði á Íslandi fyrir konur sem fæða eðlilega um leggöng og liggja stutta sængurlegu (innan við 36 klukkutíma). Slík pjónusta var heimiluð árið 2008 fyrir konur sem fæða með keisaraskurði, náist útskrift innan 48 tíma. Heimapjónusta hjúkrunarfræðinga eftir bráðakeisaraskurð hefur annars staðar reynst svara kostnaði og auka ánægju kvenna. ${ }^{6}$

Markmið pessarar rannsóknar var að skoða hvort meðallegutími við valkeisaraskurði styttist án fjölgunar endurinnlagna eftir innleiðslu flýtibatameðferðar með heimapjónustu. Jafnframt var ánægja kvenna með slíka breytingu könnuð og skoðaðir pættir sem gætu haft áhrif á lengd legutíma.

\section{Efnivið̌ur og aðferðir}

Borinn var saman meðallegutími kvenna eftir valkeisaraskurð á sængurkvennadeild Landspítala fyrir og eftir innleiðslu flýtibatameðferðar, með pví að skoða tvö heil ár, 2003 og 2007, til samanburðar við árið eftir að nýtt verkferli hófst (1.11. 2008 til og með 31.10. 2009). Gæðaeftirlit (fagrýni) var unnið samhliða breyttu verklagi. Rannsóknin var gerð með sampykki siðanefndar Landspítalans og Persónuverndar. Á kvennadeild Landspítala voru gefnar út verklagsreglur árið 2003 um umönnun kvenna eftir valkeisaraskurð sem unnið var eftir par til flýtibatameðferð var hafin í 

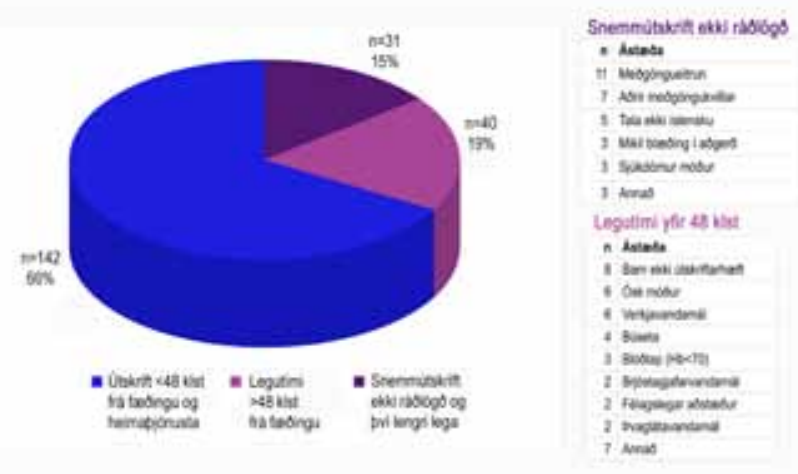

Mynd 1. Legutími kvenna sem fæeddu eitt barn með valkeisaraskurði nóvember 2008 október 2009. Í flýtibatameðferð voru 182 af 213, en 31 kona fylgdi ekki flýtibataferlinu og var rádlagt að dvelja lengur en 48 klst. Ástæður sjúkrahúslegu yfir 48 klst eru taldar upp, annars vegar hjá peim sem ráđlagt var að dvelja lengur og hins vegar peim sem fengu flýtibatameðferð en gátu ekki útskrifast snemma.

nóvember 2008. Gert var ráð fyrir að legutími gæti hafa breyst á árunum milli 2003 og 2007 án markvissra aðgerða og bæði árin pví notuð til samanburðar.

Flýtibatameðferðin var með svipuðu sniði og í Kaupmannahöfn. Allar konur sem fæddu með valkeisaraskurði fóru í flýtibataferlið, að undanskildum konum með sykursýki af tegund I eða meðgöngueitrun, peim sem ekki skildu íslensku eða gengu með fleirbura. Pær fengu hliðstæða einstaklingsmiðaða meðferð, en lega fram yfir 48 tíma var ráðlögð. Í flýtibataferlinu fólst ítarleg fræðsla sem var lykilpáttur til að gera konurnar virkar í eigin meðferð og bata. Innskriftarfræðsla fór fram viku fyrir aðgerð og stefnt að snemmútskrift (innan 48 tíma) frá upphafi. Áður hafði fræðsla aðeins farið fram daginn fyrir aðgerð án útskriftaráætlunar. Föstu frá miðnætti var breytt í sex tíma fyrir aðgerð. Konunum var leyft að drekka allt að tveimur tímum fyrir og fljótlega eftir aðgerð, en langri vökvagjöf í æð hætt. Meiri áhersla var lögð á að konur borðuðu snemma og einnig á hreyfingu eftir aðgerð. Í flýtibata er lögð áhersla á grunnverkjastillingu með föstum lyfjagjöfum um munn strax eftir aðgerð, sem ekki hafði verið markviss áður. Fastar gjafir oxýcódóns, íbúprófens og parasetamóls voru notaðar

Tafla I. Legutími kvenna sem fæddu eitt barn með valkeisaraskurði árið 2003, 2007 og eftir að flýtibatameðferð hófst 2008-9 (heil ár borin saman). Munur á legutíma frumbyrja og fjölbyrja. P-gildi: $p<0,0001$ milli 2007 og 2008-9. Milli 2003 og 2007: Frumbyrjur $p=0,50$, fjölbyrjur $p=0,001$ og allar $p=0,003$.

\begin{tabular}{|c|c|c|c|}
\hline $\begin{array}{l}\text { Valkeisaraskurðir } \\
\text { Eitt barn fætt }\end{array}$ & 2003 & 2007 & $\begin{array}{l}\text { nóv 2008- } \\
\text { okt } 2009\end{array}$ \\
\hline \multicolumn{4}{|l|}{ Frumbyrjur } \\
\hline Fjöldi kvenna & 33 & 40 & 37 \\
\hline Legutími, miðgildi (klst.) & 101 & 102 & 53 \\
\hline 25-75 hundraðshlutar (klst.) & $98-123$ & $78-120$ & $50-80$ \\
\hline \multicolumn{4}{|l|}{ Fjölbyrjur } \\
\hline Fjöldi kvenna & 166 & 143 & 176 \\
\hline Legutími, miðgildi (klst.) & 100 & 81 & 52 \\
\hline 25-75 hundraðshlutar (klst.) & $80-102$ & $76-102$ & $48-79$ \\
\hline \multicolumn{4}{|l|}{ Allar konur } \\
\hline Fjöldi kvenna & 199 & 183 & 213 \\
\hline Legutími, miðgildi (klst.) & 100 & 81 & 52 \\
\hline 25-75 hundraðshlutar (klst.) & $83-103$ & $76-103$ & $49-79$ \\
\hline
\end{tabular}

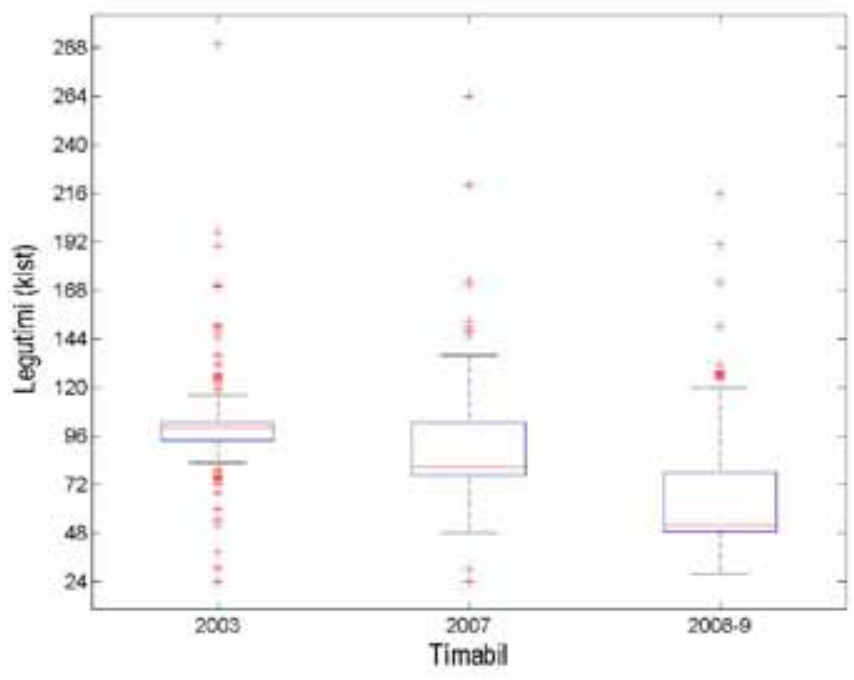

Mynd 2. Stytting legutíma við valkeisaraskurð frá 2003 til 2009. Flýtibatameðferd var innleidd í nóvember 2008. Borin voru saman heil ár 2003 og 2007 miðað við nóvember 2008 - október 2009 (heilt ár). Allar konur nema pær sem fæddu tvíbura med valkeisaraskurði.

í flýtibata, og morfín eftir pörfum. Oxýkódón var gefið í prjá sólarhringa, en konur sem útskrifuðust snemma fengu eina til tvær töflur með sér heim. Ógleðivörn var hvorki notuð í flýtibata né fyrra verklagi. Sáraumbúðir voru fjarlægðar daginn eftir í flýtibata og konan hvött til að fara í sturtu, en pað hafði áður ekki verið gert fyrr en eftir tvo sólarhringa. Valkeisaraskurðir voru að jafnaði gerðir í mænudeyfingu, eins og fyrr, nema frábending væri til staðar eða ekki tækist að deyfa. Fenýlefrín dreypi var notað til að halda blóðprýstingi stöðugum við og eftir deyfinguna í stað vökvagjafar eingöngu. Svæfing útilokaði konuna ekki frá flýtibatameðferð. Útskriftarskilyrði flýtibatameðferðar voru að kona væri sjálfbjarga, gæti hugsað um barnið, brjóstagjöf gengi vel, verkjastilling væri nægjanleg með töflum og pvaglát eðlileg. Áður voru engin sérstök útskriftarskilyrði. Við útskrift innan 48 tíma var boðin heimapjónusta ljósmóður. Ljósmóðirin mat ástand móður og barns, veitti ráðleggingar varðandi umönnun barns og brjóstagjöf, í mest átta heimsóknum.

Ef kona útskrifaðist ekki innan 48 tíma var tekin afstaða til hvað hindraði útskrift og notast við fyrirfram útbúinn krossalista. Með upplýsingum úr fæðingarskráningu var hægt að finna konur sem ekki fengu flýtibatameðferð. Sjúkraskrár peirra voru skoðaðar og útilokunarástæða skráð. Pannig mátti meta hlutfall kvenna sem fór snemma heim og fengu heimapjónustu, miðað við pær sem lágu lengur. Skoðað var hve margar útilokuðust frá flýtibatameðferð og hvort ástæður samræmdust fyrirfram ákveðnum skilmerkjum.

Íslenska fæðingarskráningin (greiningarkóði ICD-10 O82.0) var notuð til að finna allar konur sem fæddu með valkeisaraskurði á Landspítalanum á premur heilum árum, 2003, 2007 og 20089. Upplýsingar um fyrri fæðingar og fjölda fæddra barna fengust úr fæðingarskráningunni. Í hópnum 2008-9 voru allar konur meðtaldar, eins og í 2003 og 2007 hópunum, og par með einnig pær sem útilokuðust frá flýtibatameðferð. Upplýsingar um legutíma fengust úr legukerfi Landspítalans í klukkustundum frá innskrift til útskriftar. Ef kona hafði legið inni vegna meðgönguvandamála var legutími leiðréttur miðað við fæðingu 
Tafla II. Endurkomur á kvennadeild fyrir og eftir upphaf flýtibatameðferðar við valkeisaraskurð.

\begin{tabular}{|c|c|c|c|c|c|c|}
\hline \multirow{2}{*}{$\begin{array}{l}\text { Tímabil } \\
\text { Heildarfjöldi kvenna } \\
\begin{array}{l}\text { Endurkomur á kvennadeild } \\
\text { innan mánaðar frá útskrift }\end{array}\end{array}$} & \multicolumn{3}{|c|}{$\begin{array}{l}\text { Árið } 2007 \\
192 \text { konur }\end{array}$} & \multicolumn{3}{|c|}{$\begin{array}{l}\text { okt } 2008 \text { - nóv } 2009 \\
224 \text { konur }\end{array}$} \\
\hline & $\begin{array}{c}\text { Fjöldi } \\
\text { kvenna }\end{array}$ & $\begin{array}{c}\text { Fjöldi } \\
\text { skipta/konu }\end{array}$ & $\begin{array}{c}\text { Hlutfall } \\
\text { kvenna \% }\end{array}$ & $\begin{array}{c}\text { Fjöldi } \\
\text { kvenna }\end{array}$ & $\begin{array}{c}\text { Fjöldi } \\
\text { skipta/konu }\end{array}$ & $\begin{array}{c}\text { Hlutfall } \\
\text { kvenna \% }\end{array}$ \\
\hline \multicolumn{7}{|l|}{ Göngudeildarkomur } \\
\hline $\begin{array}{l}\text { Brjóstagjafarvandamál } \\
\text { (Brjóstaráđgjöf) }\end{array}$ & 17 & 1,8 & 8,9 & 17 & 1,5 & 7,6 \\
\hline $\begin{array}{l}\text { Vandamál tengd skurði } \\
\text { skurðsýkingar meðtaldar }\end{array}$ & 7 & 1,7 & 3,6 & 14 & 1,6 & $6,3^{*}$ \\
\hline $\begin{array}{l}\text { Vandamál frá legi, brjóstasýkingar, pvagfærasýkingar } \\
\text { eða hiti án skýringa }\end{array}$ & 9 & 1,4 & 4,7 & 10 & 1,2 & 4,5 \\
\hline $\begin{array}{l}\text { Annað (viðtöl við félagsráðgjafa, } \\
\text { sykursýkismóttaka og blóðprýstingsmælingar }\end{array}$ & 5 & 1,6 & 2,6 & 15 & 1,9 & $6,7^{\star \star}$ \\
\hline Endurinnlagnir & 3 & 1,3 & 1,6 & 4 & 1,0 & 1,8 \\
\hline
\end{tabular}

${ }^{*} p=0,22{ }^{* *} p=0,05$.

barns (38 konur árið 2003, 24 konur 2007, 26 konur 2008-9). Miðgildi, fjórðungamarkabil (interquartile range) og rammarit (boxplot) voru notuð til samanburðar par sem legutími fylgdi ekki normaldreifingu. Hlutfallsleg áhætta (risk ratio, RR) og 95\% öryggisbil (confidence interval, CI) var notað við samanburð á legutíma frum- og fjölbyrja. Marktækni var ákvörðuð með Wilcoxon og Kruskal-Wallis prófum. Konur sem fæddu tvíbura voru skoðaðar sér, par sem sá hópur var ekki sambærilegur með tilliti til meðgöngulengdar og fylgikvillatíðni. Par sem endurinnlagnir innan 30 daga voru mjög fáar og pví erfitt að treysta gögnum frá legukerfi, var öllum konum í hópum 2008-9 og 2007 flett upp handvirkt í Sögukerfinu og kannað hvort pær lögðust inn aftur eða komu á göngudeild, og fjöldi og ástæður skráðar. Endurinnlagnir og endurkomur 2003 voru ekki athugaðar.

Haft var gæðaeftirlit með flýtibatameðferð fyrsta árið í formi framvirkrar skráningar á sérstök eyðublöð, sem var að hluta liður í að fylgja eftir breyttu verklagi. Skráður var aldur konu, fyrri fæðingar og keisaraskurðir, pyngdarstuðull (Body Mass Index = BMI) miðað við pyngd í fyrstu mæðraskoðun (skráð í fimm flokkum) og pyngdaraukning á meðgöngu. Einnig var skráð hvenær konur borðuðu fyrst og fóru fram úr eftir fæðingu (í heilum tímum), sem og notkun ógleði- og verkjalyfja. Tengsl ofangreindra pátta við legutíma í klukkustundum voru könnuð með fylgnistuðli Spearmans og marktækni ákvörðuð, annars vegar út frá Wilcoxon raðprófi og hins vegar $\chi^{2}$ nákvæmniprófi Fishers, eftir pví sem við átti. Notast var við legutíma frá fæðingu fremur en innskrift til að forðast skekkju vegna mismunandi biðtíma fram að aðgerð. Konum var skipt eftir pví hvort snemmútskrift náðist eða ekki, og miðgildi samfelldra breyta skoðuð í peim hópum með Wilcoxon raðprófi eða Kruskal-Wallis tilgátuprófi. Miðgildi legutíma og fyrstu máltíðar var skoðaður með tilliti til notkunar ógleðilyfja. Munur var talinn marktækur ef p-gildi var $<0,05$.

Ánægja kvenna með breytta meðferð var könnuð með afturskyggnum hætti. Konur í flýtibatameðferð á tímabilinu janúar til maí 2009 fengu senda ánægjukönnun í tölvupósti premur til fimm vikum eftir útskrift. Af 62 konum svöruðu 54 (87\%). Meðal annars var spurt um hvort konu hafi fundist dvölin hæfilega löng og hvort aðstoð við brjóstagjöf og verkjastilling hafi pótt fullnægjandi.
Í niðurstöðum er annars vegar greint frá samanburði á legutíma heildarhópa kvenna sem fæddu með valkeisaraskurði á ofangreindum tímabilum, sem pá er vísað til með ártölum, og hins vegar fagrýni á flýtibatameðferð.

\section{Niðurstöður}

Legutími eftir valkeisaraskurð styttist marktækt um rúmlega sólarhring eftir innleiðslu flýtibatameðferðar, í tvo til prjá sólarhringa hjá meirihluta kvenna. Af konum sem fæddu einbura með valkeisaraskurði 2008-9, að meðtöldum peim sem ekki fengu flýtibatameðferð ( $n=31$ ), gátu 66\% útskrifast snemma (mynd 1). Miðgildi legutíma kvenna með einbura styttist úr 82 í 52 tíma milli 2007 og 2008-9 (mynd 2). Konur sem fæddu einbura fóru marktækt fyrr heim 2007 miðað við 2003, án sérstakra breytinga á meðferð, en sá munur var nær eingöngu vegna kvenna sem áttu börn fyrir (tafla I). Munur á legutíma frumbyrja og fjölbyrja var tæpur sólarhringur árið 2007 en einungis um ein klukkustund 2008-9. Meðalaldur kvennanna var 32 ár á öllum tímabilum.

Um fimm prósent af konum sem fór í valkeisaraskurð á hverju tímabilanna fæddu tvíbura. Pegar tekin voru saman öll tímabilin ( $n=34)$, lá aðeins fjórðungur pessara kvenna innan við fjögurra sólarhringa sængurlegu. Legutími kvenna með tvíbura

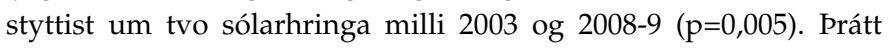
fyrir pað var miðgildi legutíma kvenna með tvíbura 116 klst árið 2008-9 miðað við 52 klst. hjá konum sem fæddu einbura á sama tímabili $(\mathrm{p}<0,0001)$.

Fjórar konur voru endurinnlagðar af heildarhópnum 2008-9 ( $\mathrm{n}=224$, fjölburameðgöngur meðtaldar), allar meira en hálfum mánuði eftir útskrift. Ein kona til viðbótar fór í aðgerð vegna sjúkdóms ótengdum keisaraskurðinum og var ekki tekin með. Árið 2007 (n=192) voru fjórar endurinnlagnir, par af lagðist ein kona tvisvar inn. Algengustu vandamálin voru sýkingar, vandamál tengd skurðsári, brjóstum eða legi (tafla II). Sama hlutfall kvenna leitaði á göngudeild bæði tímabilin vegna annarra sýkinga en i skurði eða blæðinga frá legi. Heldur fleiri komu til að láta skoða skurðinn eftir að snemmútskriftir hófust en munurinn var ekki marktækur. Ein kona fékk alvarlega skurðsýkingu á 


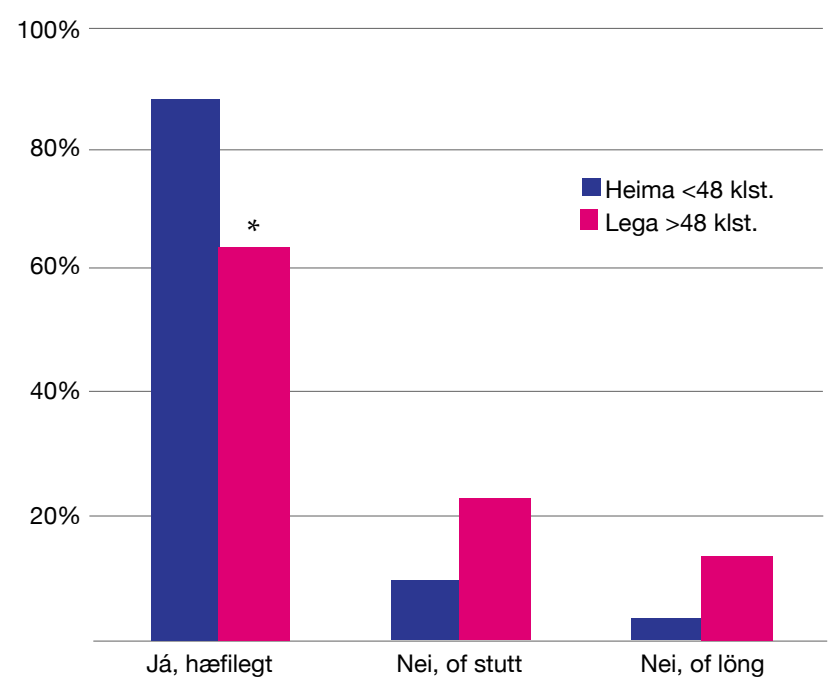

Mynd 3. Ánægja kvenna með lengd legunnar miðað við raunverulegan legutíma. Konur í flýtibatameðferð janúar - maí 2008-9 ( $\left.n=54,{ }^{*} p=0,03\right)$.

hvoru tímabili par sem purfti annars vegar innlögn (2007) og hins vegar endurteknar komur á göngudeild (2008-9). Göngudeildarkomum fjölgaði af ástæðum sem ekki töldust til fylgikvilla, pað er vegna blóðprýstingsmælinga, viðtala við félagsráðgjafa og sykursýkimóttöku ( $\mathrm{p}=0,05)$. Vegna skráningarágalla var fjöldi göngudeildarkoma vegna heftatöku ekki metinn. Aðeins 9\% kvenna 2008-9 lágu inni fimm daga eða lengur, miðað við 18\% árið 2007, en heftataka fer að jafnaði fram á fimmta degi.

Fagrýni á flýtibatameðferð fyrsta árið eftir innleiðslu

Rúmlega 80\% kvennanna 2008-9 fengu flýtibatameðferð. Í peim tilvikum par sem konur fylgdu ekki flýtibataferli var fyrirfram ráðlögð lengri lega. Í örfáum tilfellum varð asablæðing við aðgerð sem leiddi til pess að pær konur fengu ekki flýtibatameðferð. Algengasta ástæða fyrir legu í meira en tvo sólarhringa við flýtibatameðferð var að barnið gat ekki útskrifast (mynd 1). Pegar konur í flýtibatameðferð voru spurðar hvort pær teldu dvalartímann á sængurkvennadeild hæfilegan, reyndust konur sem útskrifuðust innan 48 klukkustunda ánægðari en hinar sem lágu lengur (mynd 3). Heimferðartími virtist ekki hafa áhrif á hvort konur teldu sig hafa fengið næga aðstoð við brjóstagjöf.

Pegar skoðaður var legutími fjölbyrja og frumbyrja, var ekki marktækur munur á pví hvort útskrift náðist innan 48 tíma ( $R R=1,18,95 \% C I: 0,62-2,25)$. Ekki fundust heldur tengsl milli fyrri keisaraskurða og legutíma. Tæplega 10\% af konum í flýtibatameðferð voru 25 ára og yngri. Af pessum ungu konum fóru 11 af 19 heim innan 48 klukkustunda en af peim sem voru eldri en 25 ára 139 af 173 (58\% á móti 80\%). Ungu konurnar voru pannig líklegri en pær eldri til að liggja inni meira en tvo sólarhringa $(\mathrm{p}=0,04)$.

Einungis tæpur helmingur kvennanna voru innan eðlilegra pyngdarmarka (18,5 BMI 25), en $7 \%$ voru of léttar og $44 \%$ of pungar eða offeitar. Pyngdarflokkur virtist ekki hafa áhrif á hvort útskrift náðist innan 48 klukkustunda frá fæðingu. Engin fylgni fannst milli BMI eða pyngdaraukningar á meðgöngu og legutíma.

Konur sem fengu flýtibatameðferð borðuðu að meðaltali fimm klukkustundum eftir fæðingu og allar höfðu borðað innan átta tíma. Pær fóru að jafnaði fram úr rúmi tveimur tímum eftir að pær borðuðu, pó $10 \%$ gerðu pað eftir meira en 10 tíma. Engin tengsl voru milli pess hvenær konurnar hreyfðu sig fyrst og pess hvenær pær fóru heim. Konur sem fóru heim innan 48 klukkustunda borðuðu ekki fyrr en hinar sem lágu lengur (miðgildi hópanna 4 á móti 5 klst.; p=0,11). Ellefu prósentum var gefið ógleðilyf, og tæplega helmingur peirra kastaði upp. Ekki virtist samband milli pess og að liggja lengur inni en 48 klukkustundir $(\mathrm{p}=0,08)$.

Heildarmagn morfíns á legutímanum var að meðaltali 15 mg á hverja konu, en 10\% fengu meira en $30 \mathrm{mg}$. Konur í flýtibatameðferð sem lágu lengur en 48 tíma $(\mathrm{n}=40)$, fengu marktækt meira morfín en hinar sem fóru heim innan 48 tíma (17 mg á móti 10,5 mg; p=0,0001). Munurinn skýrðist af sex konum (af 182) sem gátu ekki útskrifast snemma vegna verkja. Af konum í flýtibatameðferð sem voru spurðar $(n=54)$, töldu $94 \%$ verkjameðferð á deild fullnægjandi, en um 10\% sögðust oft eða alltaf hafa verið með verki eftir heimkomu.

\section{Umræða}

Samkvæmt niðurstöðunum var snemmútskrift með heimapjónustu möguleg hjá tveimur af hverjum premur konum sem fæddu einbura með valkeisaraskurði og pær virtust ánægðar með pað. Petta er hliðstæður árangur og náðist í Kaupmannahöfn. Par voru reyndar einungis skoðaðar konur sem fengu flýtibatameðferð, svo líklega fóru heldur fleiri snemma heim af Landspítalanum, enda heimapjónusta í boði hér.9, 16 Snemmútskriftir virtust ekki fjölga endurinnlögnum, en taka verður tölum um endurkomur með fyrirvara, vegna aukinnar rafrænnar skráningar göngudeildarkoma 2007-2009 með tilkomu Lotukerfisins. Almennt virtist ekki hafa orðið breyting á fylgikvillatíðni, pó ýmis pjónusta færðist frá legudeild yfir á göngudeildarform. Fleiri endurkomur vegna heftatöku gætu hafa fylgt flýtibatameðferð par sem fleiri konur voru farnar heim við heftatöku á fimmta degi. Fyrri fæðingar höfðu óveruleg áhrif á legutíma kvenna við flýtibatameðferð, en aldur hafði meiri pýðingu, að pví marki sem hægt er að skilja pessa tvo pætti að í úrtaki af pessari stærð. Konur sem fæddu tvíbura með valkeisaraskurði lágu lengur inni, sem vænta mátti, og útskrift innan 48 tíma er par almennt ekki raunhæfur kostur, pó pað kunni að breytast í framtíðinni. Aðrir pættir sem voru skoðaðir, par á meðal líkamspyngdarstuðull og pyngdaraukning á meðgöngu, sýndu ekki afgerandi tengsl við legutíma.

Stytting legutíma eftir valkeisaraskurð var meiri á einu ári eftir innleiðslu flýtibatameðferðar en milli áranna 2003 og 2007, og pví er ályktað að breytingin sé að stórum hluta til komin vegna nýrrar meðferðar. Styrkur rannsóknarinnar liggur í pví að allar fyrirfram ákveðnar keisarafæðingar á heilum árum voru teknar með. Ekki var hægt að útiloka truflandi pætti, né meta hvaða pættir meðferðarinnar stuðluðu helst að styttingu legutímans. Líklegt er að fræðsla og heimapjónusta vegi pungt. Áður hefur verið sýnt að með pví að breyta markmiði um legutíma og fræða konur endurtekið í meðgöngunni um snemmútskrift eftir fyrirhugaðan keisaraskurð, má stytta legutíma úr premur í tvo sólarhringa, án annarrar íhlutunar. ${ }^{7}$ Vísbendingar eru um að heimapjónusta fjölgi peim sem eru tilbúnar til snemmútskrifta eftir fæðingu og auki ánægju. ${ }^{6,17}$ Jafnframt hafa rannsóknir 
par sem borin var saman fasta og fæðuinntaka skömmu eftir keisaraskurð, sýnt um sólarhrings styttingu á sjúkrahúslegu. ${ }^{1}$ 12, 18 Stutt fasta og næring fljótt eftir aðgerð er meginatriði í flýtibatameðferðinni ${ }^{16}$ og gæti pannig einnig átt pátt í breyttum legutíma. Ekki fundust pó marktæk tengsl milli legutíma og fyrstu máltíðar pegar skoðaðar voru konur í flýtibatameðferð sem allar borðuðu innan átta klukkutíma.

Tíundu hverri konu sem fékk flýtibatameðferð var gefið ógleðilyf. Tíðni pessa vandamáls er mismunandi (4-32\%), en skilgreiningar einnig breytilegar, sem og notkun verkjalyfja. Í rannsókn á konum sem fengu morfín eftir keisaraskurð var tíðni ógleði $14 \% .^{7}$ Ógleði tengist oft penslu á kvið og vægri garnalömun. Orsakir garnalömunar eftir aðgerð eru lítt skilgreindar en tengjast hamlandi sympatískum taugaviðbrögðum, bólgu í görnum og lyfjanotkun. ${ }^{3}$ Eftir legnám purftu prisvar sinnum færri konur ógleðilyf meðal kvenna sem fóru snemma heim, miðað við hinar sem voru lengur inniliggjandi. ${ }^{12}$ Ekki var marktækur munur á pessu í okkar úrtaki. Pörf er á rannsókn á tíðni ógleði eftir keisaraskurð par sem reynt væri að meta orsakir ógleðinnar og í kjölfarið áhrif ógleðivarna. Fagrýni sýndi að fáeinar konur voru með verki sem töfðu útskrift og purftu meira morfín. Sambærilegum hópi kvenna fannst verkjastillingin heldur ekki fullnægjandi. Petta mætti bæta, en taka parf mið af pví að ógleði virðist algengara vandamál en miklir verkir. Notkun ópíóíð-lyfja getur stuðlað að ógleði, einkum við gjöf í æð. Aukin notkun er pví ekki ákjósanleg pegar verkir hamla heimferð og leita parf annarra leiða í verkjameðhöndlun.
Eftir að innlagnarferli valkeisaraskurða var endurskoðað með aðferðir flýtibatameðferðar að leiðarljósi og heimapjónusta bauðst, hafa konur útskrifast fyrr heim en áður tíðkaðist. Allar hraustar konur sem fæða fullburða börn með valkeisaraskurði ættu að hafa möguleika á snemmútskrift. Konur sem tala ekki íslensku eða fæða tvíbura ættu að fá flýtibatameðferð, og skoða parf hvort hægt sé að bjóða pessum konum heimapjónustu. Veita parf einstaklingsmiðaða meðferð pegar við á og huga vel að mjög ungum konum, auk pess að hafa augun opin fyrir nýjum meðferðarmöguleikum til verkjastillingar og ógleðivarna.

\section{Pakkir}

Birnu Björgu Másdóttur lækni, hag- og upplýsingamálum, Landspítala og Guðrúnu Garðarsdóttur ritara Fæðingarskráningar, er pakkað fyrir aðstoð við gagnaöflun. Hildi Harðardóttur yfirlækni fæðinga, meðgöngu- og fósturgreiningadeilda og starfsfólki sængurkvennadeildar og skurðstofu á kvennadeild er pökkuð aðstoð við framkvæmd rannsóknarinnar og innleiðingu flýtibataferlisins.

Samstarfshópur um innleiðslu flýtibatameðferðar við valkeisaraskurði samanstóð auk höfunda (að frátöldum tölfræðingi) af Kristínu Jónsdóttur fæðinga- og kvensjúkdómalækni, Aðalbirni Porsteinssyni yfirlækni svæfinga á kvennasviði, Guðfinnu S. Sveinbjörnsdóttur hjúkrunarfræðingi/ljósmóður og Rannveigu Rúnarsdóttir deildarstjóra meðgöngu- og sængurkvennadeilda.

\section{Heimildir}

1. Patolia DS, Hilliard RL, Toy EC, Baker B. Early feeding after cesarean: randomized trial. Obstet Gynecol 2001; 98: 113-6.

2. Izbizky GH, Minig L, Sebastiani MA, Otaño L. The effect of early versus delayed postcaesarean feeding on women's satisfaction: a randomised controlled trial. BJOG 2008; 115: 332-8.

3. Kafali H, Duvan CI, Gözdemir E, Simavli S, Onaran Y, Keskin E. Influence of gum chewing on postoperative bowel activity after cesarean section. Gynecol Obstet Invest 2010; 69: 84-7.

4. Abd-El-Maeboud KH, Ibrahim MI, Shalaby DA, Fikry MF. Gum chewing stimulates early return of bowel motility after caesarean section. BJOG 2009; 116: 1334-9.

5. Kovavisarach E, Atthakorn M. Early versus delayed oral feeding after cesarean delivery. Int J Gynaecol Obstet 2005; 90: 31-4.

6. Brooten D, Roncoli M, Finkler S, Arnold L, Cohen A, Mennuti M. A randomized trial of early hospital discharge and home follow-up of women having cesarean birth. Obstet Gynecol 1994; 84: 832-8.

7. Strong TH Jr, Brown WL Jr, Brown WL, Curry CM. Experience with early postcesarean hospital dismissal. Am J Obstet Gynecol 1993; 169: 116-9.
8. Bossert R, Rayburn WF, Stanley JR, Coleman F, Mirabile CL Jr. Early postpartum discharge at a university hospital. Outcome analysis. J Reprod Med 2001; 46: 39-43.

9. Degn-Petersen B, Carlsen H, Weber T, Rasmussen YH, Kehlet $\mathrm{H}$. Accelereret patientforløb efter sectio. Ugeskr Læge 2004; 166: 2254-8.

10. Bülow-Lehnsby AL, Grønbeck L, Krebs L, et al. Komplikationer i forbindelse med kejsersnit i elektivt sectio-team. Ugeskr Læge 2006; 168: 4088.

11. Valgeirsdóttir $H$, Harðardóttir $H$, Bjarnadóttir RI. Fylgikvillar við keisaraskurði. Læknablaðið 2010; 96: 37-42.

12. Summitt RL Jr, Stovall TG, Lipscomb GH, Washburn SA, Ling FW. Outpatient hysterectomy: determinants of discharge and rehospitalization in 133 patients. Am J Obstet Gynecol 1994; 171: 1480-4; discussion 1484-7.

13. Magnesi L, Hofmeyr GJ. Early compared with delayed oral fluids and food aftur caesarean section. Cochrane Database of Systemic Reviews 2002, Issue 3. Art. No.:CD003516.DOI:10.1002/14651858.CD003516

14. Kehlet $\mathrm{H}$. Multimodal approach to postoperative recovery. Curr Opin Crit Care 2009; 15: 355-8.
15. Kehlet H, Dahl JB. Anaesthesia, surgery and challenges in postoperative recovery. Lancet 2003; 362; 1921-8

16. Bülow-Lehnsby AL, Grønbeck L, Krebs L, Langhoff-Roos J. Elektivt sectio-team - en organisatorisk nyskabelse. Ugeskr Læger 2006;168: 4085-8.

17. Brooten D, Knapp H, Borucki L, et al. Early discharge and home care after unplanned cesarean birth: nursing care time. J Obstet Gynecol Neonatal Nurs 1996; 25: 595-600.

18. Göçmen A, Göçmen M, Sarao lu M. Early post-operative feeding after caesarean delivery. J Int Med Res 2002; 30: 506-11.

19. Kramer RL, Van Someren JK, Oualls CR, Curet LB, Postoperative management of cesarean patients: the effect of immediate feeding on the incidence of ileus. Obstet Gynecol 1996; 88: 29-32. 